\title{
Root Pruning at Planting and Planting Depth in the Nursery Impact Root System Morphology and Anchorage
}

\author{
Edward F. Gilman and Christine Wiese
}

\begin{abstract}
Quercus virginiana Mill. Highrise ${ }^{\circledR}$ were planted into $10 \mathrm{~L}$ and then $57 \mathrm{~L}$ plastic nursery containers at two depths for a total of four depth combinations, and then root pruned in one of three different manners when planted into the landscape. Nursery planting depth had no impact on growth in the nursery or bending moment required to tilt trunks in the first two years following landscape planting. Root pruning when planting into landscape by either method tested had no effect on growth the first two years. Number of roots circling inside the root ball was reduced by shaving or deep root ball slicing two growing seasons after planting. Root balls that were either sliced or shaved generated more roots in landscape soil one growing season after landscape planting than those that were not root pruned, which probably explained the greater bending moment required to pull trees out of the ground. Total crosssectional root area one growing season after landscape planting was greater on shaved trees than those not root pruned at planting. Bending moment at 20 degrees trunk tilt was best correlated with cross sectional area of roots growing straight across the periphery of the root ball and into landscape soil. Key Words. Anchorage; Circling Roots; Landscape Planting; Lateral Stability; Root Ball Shaving; Root Ball Slicing; Stability.
\end{abstract}

Nursery production method influences root morphology and tree stability or anchorage. Naturally regenerated Scots pine (Pinus sylvestris $\mathrm{L}$.) were more stable during winching tests than trees planted from $5 \mathrm{~cm}$ diameter containers, probably due to a combination of more root cross sectional area, better root symmetry, and increased number of straight roots (Lindstrom and Rune 1999). Root systems on plantation trees planted from containers often have more constricted, circling, and kinked roots, making trees less stable than naturally generated trees (Nichols and Alm 1983; Blanusa et al. 2007). Sparks (2005) found that after three years, weakly developed lateral or brace roots on deeply planted Carya illinoinensis (Wangenh.) trees resulted in more tilting or blowing over during a hurricane. Lyons et al. (1983) found that after two years, Malus pumila (Mill.) were less likely to be shaken loose by wind when installed at nursery depth than when planted up to $20 \mathrm{~cm}$ below nursery depth. The difference in stability between naturally regenerated trees and trees planted from propagation-sized containers has been shown to decrease over time, for a number of species, as roots grow in strength to compensate for irregular root distribution and bends (Nichols and Alm 1983; Coutts et al. 1999). Except for one study (Gilman and Masters 2010) that showed that field-grown plants were more stable in wind three years after planting than those planted from smooth-sided $170 \mathrm{~L}$ containers, there is little anchorage data available for trees planted from landscape-sized containers.

Root deformation from containers may impact stability more on trees, such as pines, which lack the capacity to initiate adventitious roots or are unable to graft roots together (Halter et al. 1993). Quercus virginiana Mill. Cathedral Oak ${ }^{\circledR}$ trees can generate new straight roots above root deformations by forming adventitious roots (Gilman and Harchick 2008). However, as trees grew older than about two years Cathedral Oak lost its capacity to generate adventitious roots. This suggests that some trees planted from large containers, such as those used in the landscape profession, could have many of their roots deflected by the container wall, even on trees capable of forming adventitious roots when young.

Although slicing (Gilman et al. 2008) or shaving (Gilman et al. 2010b) root balls when shifting from one container size to another can increase total number of roots and number of straight roots in the root ball in a production nursery, there is less information about planting landscape-sized trees into field soil. Krasowski and Owens (2000) found that mechanically root pruned Picea glauca (Moench) Voss liners produced greater root growth than control or chemically root pruned treatments despite having a smaller root ball as a result of root pruning at planting. Gilman et al. (1996) showed that shallow (2.5 $\mathrm{cm}$ deep) slicing of $11 \mathrm{~L}$ container root balls top-to-bottom on shrubs [Ilex cornuta (Lindl. \& Paxt.) 'Burfordii'] at planting into field soil resulted in a redistribution of roots, not an increase in roots compared with non-pruned controls. Lightly scoring or teasing the root ball periphery from slightly larger trees (Tilia cordata Mill. and Salix alba) from 25 to $40 \mathrm{~L}$ containers also had no impact on number of roots growing into landscape soil (Welcherding et al. 2007). One study on Cathedral Oak trees that were $8 \mathrm{~cm}$ caliper at planting showed that shallow slicing of $170 \mathrm{~L}$ root balls $(2.5 \mathrm{~cm}$ deep into the side surface) in several places top to bottom had no impact on root growth or lateral stability three years after planting (Gilman and Masters 2010).

Objectives of the present study were to compare anchorage (lateral stability), root form, and growth on container-grown trees 
produced with different planting depth strategies and then subjected to various root pruning methods at planting into landscape soil.

\section{MATERIALS AND METHODS}

\section{Nursery Growing}

In March 2005, 110 stem cuttings ( $22 \mathrm{~cm}$ tall, 3 to $4 \mathrm{~mm}$ stem diameter) of Quercus virginiana Mill. Highrise ${ }^{\circledR}$ rooted in square $6.9 \mathrm{~cm}$ across $\times 14 \mathrm{~cm}$ deep smooth-sided containers (Anderson Die and Manufacturing, Portland, Oregon, U.S., model 03ANBAN2_7-8 x 5), were planted into $10 \mathrm{~L}(27 \mathrm{~cm}$ across top and bottom, $20 \mathrm{~cm}$ deep) Air-Pot ${ }^{\mathrm{TM}}$ cylindrical black plastic containers (Caledonian Tree Company, Ltd., Scotland). The point where the top-most woody root emerged from the stem was placed either $13 \mathrm{~mm}$ (shallow) or $64 \mathrm{~mm}$ (deep) below substrate surface. Trees were spaced pot-to-pot (i.e., touching one another) except for a $1.8 \mathrm{~m}$ wide corridor every four rows. Irrigation was applied two or three times daily in the growing season through October 2005, totaling $3.8 \mathrm{~L}$ through one Roberts (Roberts Irrigation Products, Inc., San Marcos, Idaho, U.S.) Spot-Spitter per container.

In late March 2006, trees were shifted into $57 \mathrm{~L}$ (47 cm across top and bottom, $30 \mathrm{~cm}$ deep) Air-Pot containers, whereby half the trees for each $10 \mathrm{~L}$ planting depth were positioned at grade $(10 \mathrm{~L}$ substrate surface even with $57 \mathrm{~L}$ substrate surface ) or deep (10 L substrate surface $64 \mathrm{~mm}$ below $57 \mathrm{~L}$ substrate surface). A total of four planting depth combinations resulted from the two planting sessions: 1) $13 \mathrm{~mm}$ deep into $10 \mathrm{~L}, 0 \mathrm{~mm}$ deep into $57 \mathrm{~L}$; 2) $64 \mathrm{~mm}$ deep into $10 \mathrm{~L}, 0 \mathrm{~mm}$ deep into $57 \mathrm{~L}$; 3$) 13 \mathrm{~mm}$ deep into $10 \mathrm{~L}, 64$ $\mathrm{mm}$ deep into $57 \mathrm{~L}$; and 4) $64 \mathrm{~mm}$ deep into $10 \mathrm{~L}, 64 \mathrm{~mm}$ deep into $57 \mathrm{~L}$. No roots were pruned or mechanically manipulated in any way at any time during the nursery production phase of the study. Trees in $57 \mathrm{~L}$ containers were spaced $2.4 \mathrm{~m}$ apart and irrigated three times daily (weather dictating) in the growing season with a maximum of $15 \mathrm{~L}$ through two Roberts Spot-Spitters. Trees were pruned and trunks staked in 2006 and 2007 to develop one leader and trees were secured to a trellis system for stability in wind.

Substrate was 50:40:10 (New Florida peat: pine bark: sand, volume). New Florida peat is a compost of Florida peat and hardwood bark fines (Florida Potting Soil, Inc., Orlando, Florida, U.S.). Fertilizer (18-5-10 controlled release, Harrell's Inc., Lakeland, Florida, U.S.) was incorporated into substrate prior to planting at $10.74 \mathrm{~kg} / \mathrm{m}^{3}$, and no other fertilizer was applied. Weeds were periodically pulled from container substrate. Trees did not root out of pots and into the ground. The plot was located in USDA hardiness zone $8 \mathrm{~b}$ in Gainesville, Florida.

\section{Landscape Planting}

On March 24 and 25, 2008, 48 trees (12 from each planting depth combination) closest to the mean caliper $(3.1 \mathrm{~cm}$ caliper, $2.56 \mathrm{~m}$ tall) for all trees in $57 \mathrm{~L}$ containers in the study were planted into a field soil of Millhopper fine sand (loamy, silicaceous, hyperthermic Grossarenic Paleudults) with less than 2\% organic matter and a bulk density of $1.51 \mathrm{~g} / \mathrm{cc}$. Holes 10 to 15 $\mathrm{cm}$ wider than the root balls were hand dug with straight sides and flat bottoms and adjusted so the top of the undisturbed root ball was about even with the landscape soil surface. The bottom of the holes were tamped by foot from the same person evenly around the bottom of the planting hole in an effort to standardize settling that might occur. Once the root ball was placed in the planting hole, a $15 \mathrm{~cm}$ wide volume of undisturbed soil at the edge of hole was loosened as deep as the root ball and pushed into the hole. The rest was filled with soil that came out of the planting hole. Water was added to settle backfill soil and soil was packed firmly with the same person's foot. The same person did the packing in an effort to standardize compaction of backfill soil. No berm or water ring was constructed around the root balls and no mulch was applied. Weeds were kept clear in a $1 \mathrm{~m}$ wide strip down each row with periodic applications of Glyphosate.

Trees from each of the four planting depths in containers were root pruned using two different methods and a non-pruned control within a few minutes of planting into the field for a total of twelve treatment combinations. The root pruning methods were: 1) no root pruning; 2) root ball shaved by inserting a sharp square-tip balling spade into the root ball top surface tangent to the trunk 3 to $6 \mathrm{~cm}$ inside the periphery all the way to the bottom of the root ball once trees were planted and backfill was added (root ball took on a heptagon shape viewed from above, Figure 1 ); and 3) root ball radial slicing by cutting 10 to $12 \mathrm{~cm}$ radially into the top of the root ball through the bottom in six equidistant places with a sharp square-tip balling spade once trees were planted and backfill was added (Figure 1). Prior to planting trees into the landscape in treatments 2 and 3 , a hand pruner was used to remove substrate and roots all around the top outer corner of the root ball by cutting at a 45 degree angle about $3 \mathrm{~cm}$ deep in an effort to remove circling roots in the very top of the ball.

The 48 trees were arranged $1.8 \mathrm{~m}$ apart in rows $3 \mathrm{~m}$ apart in a randomized complete block design (4 planting depths in containers $\times 3$ root pruning methods at landscape planting randomized within each of 4 blocks). Planted trees were irrigated three times daily totaling $11 \mathrm{~L}$ through one Roberts Spot-Spitter through October 2008. In November 2008, irrigation was changed to $6 \mathrm{~L}$ daily. Daily irrigation was applied the following growing season. Irrigation was applied primarily to the root ball surface, although a small amount landed on landscape soil beyond the root ball. Each tree was fertilized with $200 \mathrm{~g}$ of granular 16-4-8 (Diamond R Fertilizer Company, Ft. Pierce, Florida, U.S.) on May 2008 and $400 \mathrm{~g}$ on August and September 2008, and March and June 2009 by surface application to a circular area with a radius of $45 \mathrm{~cm}$ centered on the trunk.

\section{Evaluating Anchorage}

Half of the trees from each of the twelve treatment combinations (i.e., two complete blocks chosen at random) were pulled out of the ground in November 2008 (referred to as GS 1) and the other half in September 2009 (GS 2) to evaluate anchorage (lateral stability) approximately one and two growing seasons after planting. An electronic inclinometer (model N4; Rieker Inc., Aston, Pennsylvania, U.S.) was mounted to a fabricated steel plate $(5.1 \times 7.6 \mathrm{~cm})$ secured to the trunk base $8 \mathrm{~cm}$ from soil surface, which was above the swollen root flare. A $3,629 \mathrm{~kg}$ capacity load cell (SSM-AF-8000; Interface Inc., Scottsdale, Arizona, U.S.) was placed in-line with the pulling cable attached to the trunk $30 \mathrm{~cm}$ above inclinometer. Trunks were pulled in the 270 degrees Azimuth (from north) direction with the cable parallel to ground. The cable was pulled at a rate of $2 \mathrm{~cm} \bullet \mathrm{s}^{-1}$ with an electric winch mounted to a tractor until the roots were completely out of the soil and the trunk was horizontal. Soil moisture con- 


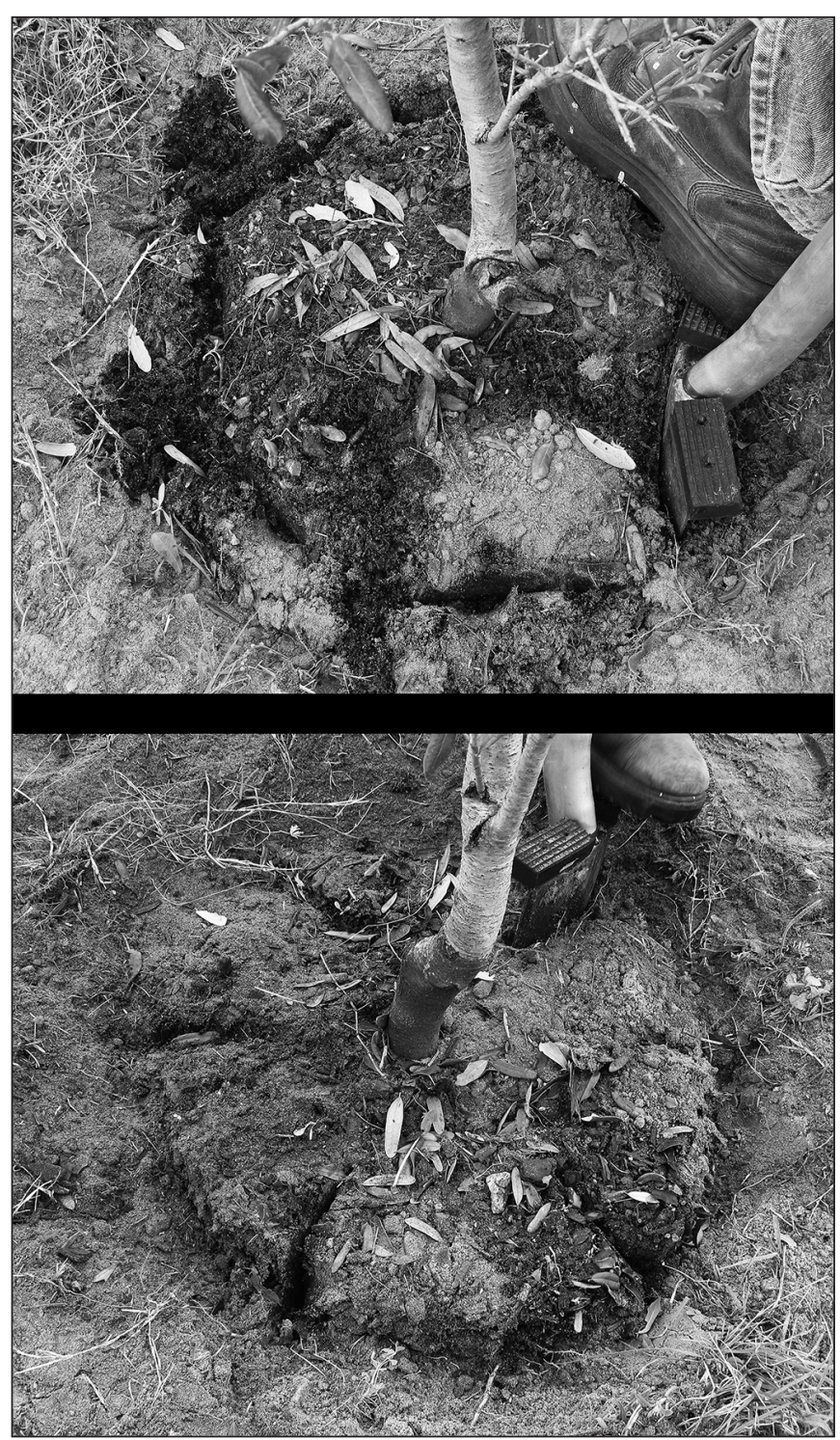

Figure 1. Shaving (top) or slicing (bottom) root balls immediately after planting. Shaving severed 3 to $6 \mathrm{~cm}$ of roots and substrate from the root ball periphery but left them in place as shown.

tent was standardized across trees for each growing season by waiting until no rain was predicted for the two-day pulling event, although soil moisture for the GS 1 pull (total of $2.8 \mathrm{~cm}$ rainfall occurred in the two weeks prior) may have been different than in GS 2 pull (total of $8.1 \mathrm{~cm}$ rainfall occurred in two weeks prior).

Load cell and inclinometer measurements during pulling tests were sampled at $2 \mathrm{~Hz}$ (twice each second) using a 16-bit data acquisition system (National Instruments Corporation, Austin, Texas, U.S.) and displayed and archived in real-time on a laptop running LabView software (v: 7.0; National Instruments, Austin, Texas, U.S.). Trunk bending stress at position of inclinometer was calculated as: (pulling force $\times$ distance from pulling point to inclinometer $x$ trunk radius at inclinometer center $) \div\left(0.25 \pi \times\right.$ trunk radius $\left.^{4}\right)$ after James and Kane (2008). Bending moment at position of inclinometer was calculated as force $\times$ distance from pulling point to inclinometer.

\section{Tree Measurements}

Tree height was measured with a height stick and trunk diameter $15 \mathrm{~cm}$ from ground (caliper) was measured with a diameter tape at landscape planting and at the end of each subsequent growing season in September of 2008 and 2009. Immediately after trees were pulled from the ground, all roots $\geq 3 \mathrm{~mm}$ in diameter were measured at the point just beyond the periphery of the original $57 \mathrm{~L}$ container root ball. Each root ball was divided into eight 45 degree wedge-shaped sections (N, NE, E, SE, S, SW, W, NW) marked with spray paint on the root ball top and bottom. The root ball was washed of substrate and soil. Root measurements included diameter (measured with a micro-caliper), quadrant location, distance between root ball periphery and tip of root when following the largest root at forks (in those few instances where roots had broken from the pulling operation, measurement terminated at the break), whether root emerged from the top or bottom half of the original root ball, and whether the measured root grew from a root that circled in the root ball more than a 90 degree arc (in these cases, the measured root was classified as a circling root) or not (these were classified as straight roots). Root data measured just beyond the root ball periphery was used to calculate a number of other attributes (Table 1). Roots greater than 3 $\mathrm{mm}$ diameter within the root ball that circled at the position of the $10 \mathrm{~L}$ or $57 \mathrm{~L}$ container were counted and their diameter measured where they appeared to first encounter the container periphery.

\section{Statistical Analysis}

Data were analyzed in a randomized complete block design with one tree from each nursery planting depth $(4) \times$ root pruning at landscape planting (3) combination in each of four blocks. Twoway analysis of variance in the GLM procedure within SAS (SAS Institute, Cary, North Carolina, U.S.) was used to evaluate impact of main effects and interactions on measured parameters for each year independently. The two main effects were planting depth into containers and root pruning at landscape planting. Means of main effects were separated with Duncan's multiple range test. Pearson's correlation coefficient (SAS Institute, Cary, North Carolina, U.S.) was used to make correlations between root attributes and bending moment or bending stress. Significant results were reported at $P<0.05$ unless indicated.

\section{RESULTS AND DISCUSSION}

All 48 trees survived and grew following planting into the landscape; no dieback or leaf drop (other than normal leaf drop for this tree in late winter) occurred on any tree. Further study should test root pruning followed by less intense irrigation, which would be typical in landscape plantings. No interactions were statistically significant. Planting depth when shifting rooted cuttings into $10 \mathrm{~L}$ containers or when shifting $10 \mathrm{~L}$ into $57 \mathrm{~L}$ containers had no impact on trunk caliper $(3.1 \mathrm{~cm}, P=0.52)$ or tree height $(256 \mathrm{~cm}, P=0.78)$ of finished trees in the nursery in 57 L containers (data not shown). Gilman and Harchick (2008) also found that planting depth had no effect on growth of Cathedral Oak when shifting from one container size to the next up to 170 L. Other taxa showed little or no impact (Gilman et al. 2010a) or slower growth (Brown and Tilt 1992; Bryan et al. 2010) when planted deeply in containers. Planting depth in nursery containers had no impact on trunk caliper $(7.9 \mathrm{~cm}, P=0.83$, data 
Table 1. Effects of root pruning at planting and nursery planting depth in the container on root attributes $3 \mathrm{~cm}$ beyond the edge of the root ball one and two growing seasons after planting into the landscape.

\begin{tabular}{|c|c|c|c|c|}
\hline \multirow[b]{2}{*}{ Root attributes } & \multicolumn{2}{|c|}{$\begin{array}{l}\text { One growing season } \\
\text { after planting GS } 1\end{array}$} & \multicolumn{2}{|c|}{$\begin{array}{l}\text { Two growing seasons } \\
\text { after planting GS } 2\end{array}$} \\
\hline & $\begin{array}{l}\text { Root pruning } \\
\text { effect }\end{array}$ & $\begin{array}{l}\text { Planting depth } \\
\text { effect }\end{array}$ & $\begin{array}{l}\text { Root pruning } \\
\text { effect }\end{array}$ & $\begin{array}{l}\text { Planting depth } \\
\text { effect }\end{array}$ \\
\hline Total number growing into landscape soil & $\mathrm{N}^{\mathrm{z}}$ & $\mathrm{N}$ & $\mathrm{N}$ & $\mathrm{N}$ \\
\hline Total number growing from the top of root ball & $\mathrm{S}$ & $\mathrm{S}$ & $\mathrm{N}$ & $\mathrm{N}$ \\
\hline Total number growing from the bottom half of root ball & $\mathrm{N}$ & $\mathrm{N}$ & $\mathrm{N}$ & $\mathrm{N}$ \\
\hline Total number or cross sectional area of circling roots inside root ball & $\mathrm{N}$ & $\mathrm{N}$ & $\mathrm{S}$ & $\mathrm{N}$ \\
\hline Total cross sectional area growing into landscape soil & $\mathrm{N}$ & $\mathrm{N}$ & $\mathrm{N}$ & $\mathrm{N}$ \\
\hline Total cross sectional area growing from the top half of root ball & $\mathrm{S}$ & $\mathrm{N}$ & $\mathrm{N}$ & $\mathrm{N}$ \\
\hline Total cross sectional area growing from the bottom half of root ball & $\mathrm{N}$ & $\mathrm{N}$ & $\mathrm{N}$ & $\mathrm{N}$ \\
\hline Mean cross sectional area growing into landscape soil & $\mathrm{N}$ & $\mathrm{N}$ & $\mathrm{S}$ & $\mathrm{N}$ \\
\hline Mean cross sectional area growing from the top or bottom half of root ball & $\mathrm{N}$ & $\mathrm{N}$ & $\mathrm{N}$ & $\mathrm{N}$ \\
\hline Mean diameter of five largest roots & $\mathrm{N}$ & $\mathrm{N}$ & $\mathrm{N}$ & $\mathrm{N}$ \\
\hline Mean root spread radially & $\mathrm{N}$ & $\mathrm{N}$ & $\mathrm{N}$ & $\mathrm{N}$ \\
\hline
\end{tabular}

${ }^{\mathrm{z}} \mathrm{N}=$ not significant; $\mathrm{S}=$ significant at $P<0.05$.

not shown) or tree height $(4.1 \mathrm{~m}, P=0.91)$ in the two growing seasons following planting into landscape soil mostly in agreement with Bryan et al. (2010). Planting depth in the nursery containers also had no impact on bending moment required to tilt trunks to any angle one and two growing seasons after landscape planting $(P=0.82$, data not shown). Gilman and Grabosky (2011) also found no impact of landscape planting depth on live oak anchorage even six years after planting trees that were slightly larger at planting than those used in the current study.

Planting depth in containers impacted only one attribute on roots that grew into landscape soil (Table 1). Total number of roots growing from the top half of the root ball into soil one growing season after landscape planting was affected by depth of planting in the nursery container $(P=0.01)$, but not two growing seasons after planting $(P=0.56)$ (Table 2$)$. Trees planted $64 \mathrm{~mm}$ deep into $10 \mathrm{~L}$ containers generally produced fewer roots into landscape soil than trees planted shallower.

Root pruning by either method tested when planting into the landscape had no effect on subsequent trunk caliper $(P=0.83)$ or tree height $(P=0.40)$ for the first two years (data not shown) similar to Cathedral Oak live oak planted from $170 \mathrm{~L}$ containers (Gilman and Masters 2010). Reported effects of manual root pruning much smaller trees planted from containers on crown growth vary. Some authors found reduced crown growth following transplanting into field soil when container grown seedlings were root pruned at planting (Arnold and Young 1991; Arnold 1996). Persson (1978) found that mortality rate of Pinus sylvestris L. and Pinus contorta Douglas $\times$ Louden was not affected by root pruning at planting. Tree height and root collar diameter were reduced in the heavily ( $70 \%$ root mass removed) root pruned compared to light (35\% root mass removed) treatment. In contrast, Krasowski and Owens (2000) reported that Picea glauca (Moench) Voss seedlings in mechanically pruned treatments had greater aboveground growth after three growing seasons than trees that were not root pruned at planting. Tree age, soil, irrigation management, and weather likely account for at least some of the variation in results among these studies.

The number of roots growing into landscape soil from the top half of the root ball, and total cross sectional area of all roots, one growing season after planting was affected by root pruning treatment (Table 3). Root balls that were either sliced or shaved generated more roots in soil one year after landscape planting than those that were not root pruned, and total root cross sectional area one year after landscape planting was greater on shaved $(P$ $=0.02)$ and sliced $(P=0.06)$ trees than those not root pruned at planting. Mean cross sectional area of roots growing into landscape soil two growing seasons after planting was greater for trees that were sliced at planting than trees that were not root pruned. Krasowski and Owens (2000) found that root systems of mechanically pruned Picea glauca (Moench) Voss seedlings produced greater root growth than non-pruned or chemically root pruned treatments. Blanusa et al. (2007) showed that a light cutting of circling roots on shrub root balls enhanced amount of roots growing into $3 \mathrm{~L}$ container substrate outside the original pruned root ball. In contrast, Gilman et al. (1996) found on larger plants that shallow slicing $11.3 \mathrm{~L}$ container root balls top to bottom on Burford holly (Ilex cornuta 'Burfordii') at planting into field soil resulted in a redistribution of roots, not an increase in roots compared with non-pruned controls. Welcherding et al. (2007) essentially found no response to lightly scoring or teasing roots from the root ball (25 to $40 \mathrm{~L}$ ) periphery of Tilia cordata Mill. and Salix alba, the same for live oak planted from $170 \mathrm{~L}$ containers (Gilman and Masters 2010). Perhaps scoring (slicing) is more beneficial on smaller than larger-sized containers.

Root pruning at planting increased tree anchorage, but differently in the two growing seasons after planting. Bending moment required to tilt trunks to 70 degrees from vertical, and the maximum moment during the pull, was higher one growing season after planting for root balls that were shaved or sliced than trees not pruned at planting (Figure 2, left). Bending moment required to tilt trunks between 20 and 60 degrees at the end of the second growing season was greater for trees whose root balls were shaved

Table 2. Number of roots growing into landscape soil from the top half of the root ball one and two growing seasons after landscape planting.

\begin{tabular}{lll}
\hline $\begin{array}{l}\text { Planting depths into } \\
10 \mathrm{~L} / 57 \mathrm{~L} \text { containers }\end{array}$ & $\begin{array}{l}\text { One growing season } \\
\text { after planting (GS 1) }\end{array}$ & $\begin{array}{l}\text { Two growing seasons } \\
\text { after planting (GS 2) }\end{array}$ \\
\hline $13 \mathrm{~mm} /$ at grade & $13.0 \mathrm{ab}^{\mathrm{z}}$ & $13 \mathrm{a}$ \\
$13 \mathrm{~mm} / 64 \mathrm{~mm}$ & $14.8 \mathrm{a}$ & $11.3 \mathrm{a}$ \\
$64 \mathrm{~mm} / \mathrm{at}$ grade & $6.0 \mathrm{~b}$ & $7.5 \mathrm{a}$ \\
$64 \mathrm{~mm} / 64 \mathrm{~mm}$ & $6.7 \mathrm{~b}$ & $11.8 \mathrm{a}$ \\
\hline
\end{tabular}

${ }^{\mathrm{z}}$ Means in a column with a different letter are statistically different at $P<0.02$ using Duncan's multiple range test; based on six trees per planting depth averaged across root pruning treatments. 
Table 3. Effect of three root pruning methods on root attributes of Highrise live oaks.

\begin{tabular}{|c|c|c|c|c|c|c|}
\hline \multirow[t]{2}{*}{$\begin{array}{l}\text { Root pruning } \\
\text { method }\end{array}$} & \multicolumn{2}{|c|}{$\begin{array}{l}\text { Number of roots in landscape } \\
\text { soil growing from top } \\
\text { half of root ball }\end{array}$} & \multicolumn{2}{|c|}{$\begin{array}{l}\text { Total root cross sectional } \\
\text { area }\left(\mathrm{mm}^{2}\right) \text { growing } \\
\text { into landscape soil }\end{array}$} & \multicolumn{2}{|c|}{$\begin{array}{l}\text { Mean root cross sectional } \\
\text { area }\left(\mathrm{mm}^{2}\right) \text { growing } \\
\text { from root ball }\end{array}$} \\
\hline & $\mathrm{GS} 1^{z}$ & GS 2 & GS 1 & GS 2 & GS 1 & GS 2 \\
\hline Not pruned & $6 b^{y}$ & $13.1 \mathrm{a}$ & $103.3 \mathrm{~b}$ & $695.1 \mathrm{a}$ & $17.7 \mathrm{a}$ & $49.1 \mathrm{~b}$ \\
\hline Sliced & $12 \mathrm{a}$ & $9.9 \mathrm{a}$ & $192.7 \mathrm{ab}^{\mathrm{x}}$ & $775.9 \mathrm{a}$ & $16.8 \mathrm{a}$ & $73.1 \mathrm{a}$ \\
\hline Shaved & $12 \mathrm{a}$ & $9.8 \mathrm{a}$ & $268.4 \mathrm{a}$ & $776.5 \mathrm{a}$ & $18.7 \mathrm{a}$ & $63.7 \mathrm{ab}$ \\
\hline
\end{tabular}

${ }^{\mathrm{z}}$ One growing season (GS 1) or two growing seasons (GS 2) after landscape planting.

y Means in a column with a different letter are statistically different at $P<0.05$. Based on eight trees per root pruning treatment averaged across nursery planting depths.

${ }^{x}$ Significantly different from not pruned at $P<0.06$.

at planting compared to those sliced at planting (Figure 2, right). In contrast, the shallow slicing on $170 \mathrm{~L}$ containers in Gilman and Masters (2010) resulted in no increase in root number or cross sectional area growing into landscape soil, and no corresponding impact on anchorage. Perhaps the increased anchorage on sliced trees at the end of the first growing season of the current study resulted from the much deeper slicing extending 10 to $12 \mathrm{~cm}$ inside the root ball compared to the relatively shallow slicing tested in Gilman and Masters (2010) and Welcherding et al. (2007). Deep slicing in the current study cut some roots that were circling at the position of the $10 \mathrm{~L}$ container. Further testing could determine if a combination of deep slicing and shaving would be most effective; however, root balls of at least some species (e.g., Acer spp.) might be too dense to slice as deeply as in the current study.

The number and cross sectional area of roots circling within the $57 \mathrm{~L}$ root ball dimensions two growing seasons after landscape planting was dramatically reduced by either slicing or shaving at planting (Table 4). Root pruning by either method reduced the ratios of number and CSA of circling roots:noncircling roots in both years meaning that a larger portion of the root system grew in a radial direction away from the trunk (straight roots) than tangent to or circling the trunk. Seven temperate and tropical trees also produced more straight roots growing radially within a $57 \mathrm{~L}$ container root ball in response to shaving away all roots at the $10 \mathrm{~L}$ container root ball periphery prior to shifting (Gilman et al. 2010b). The positive response to shaving off the entire root ball periphery or deep $(10$ to $12 \mathrm{~cm})$ radial slicing in the current study was probably due to the increased amount of roots severed compared to the shallow slicing, teasing, or scoring in the studies cited previously. Just like trees dug from a field nursery, trees from containers appear to tolerate severe root pruning at planting.

Bending moment at 20 degrees trunk tilt combining data from all 48 trees across both years was best correlated $(r=0.80)$ with CSA of straight roots (Table 5). This correlation suggested that the presence of abundant roots that grew out into landscape soil without deflection by the container wall is crucial for optimum tree anchorage. Also highly correlated with bending moment was the sum of all root CSA in the leeward direction ( $\mathrm{r}$ $=0.63, \mathrm{~W}, \mathrm{NW}$, and $\mathrm{SW} 1 / 8$ circumference sections), total root CSA growing into landscape soil $(\mathrm{r}=0.55)$, root CSA leeward (west) $1 / 8$ section $(r=0.49)$, and the sum of the root CSA in the windward direction (E, NE, and SE $1 / 8$ sections; $r=0.47$ ) (Table 5). Anchorage of another cultivar of live oak (Cathedral Oak) from similarly sized containers to those used in the current study three years after landscape planting was most correlated

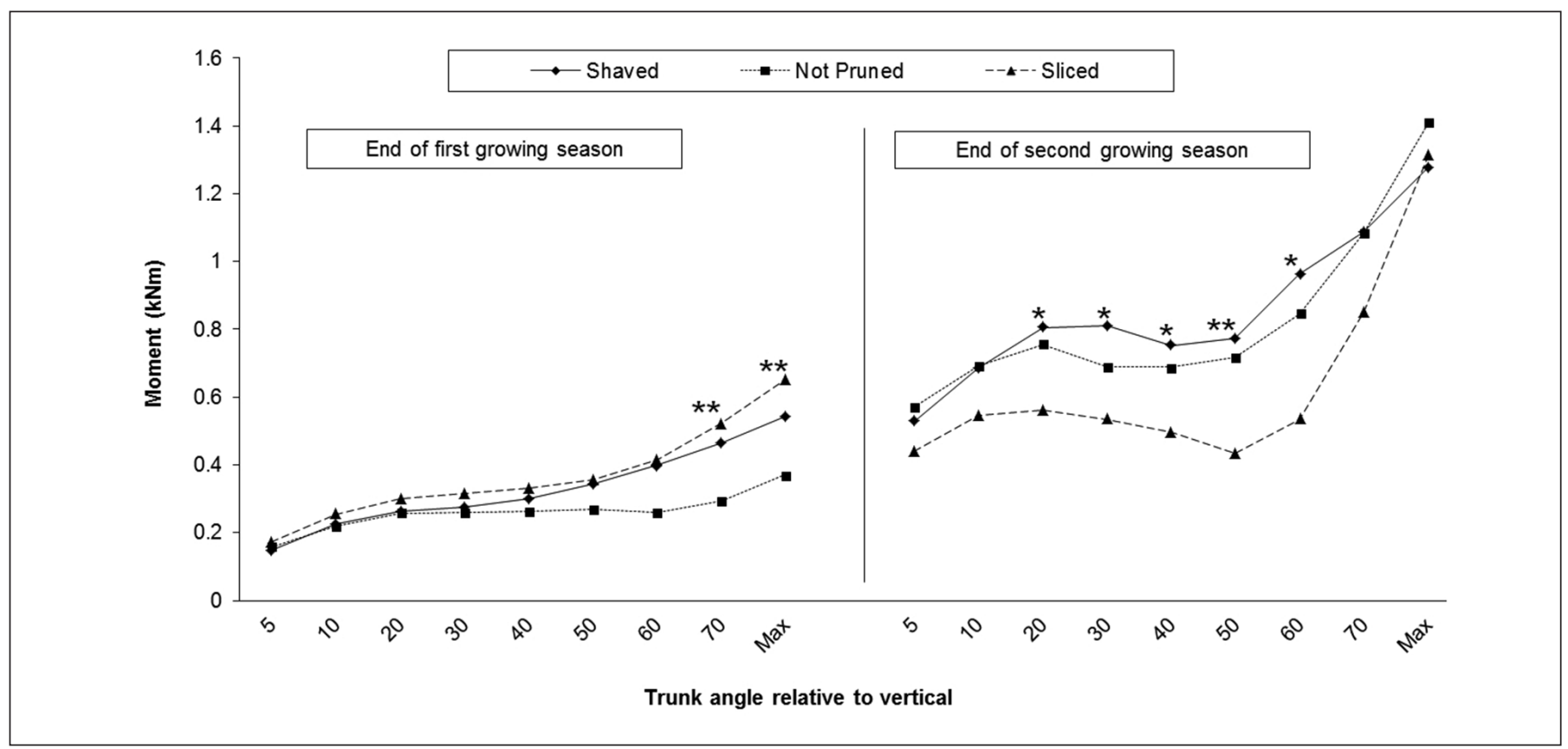

Figure 2. Bending moment $(\mathrm{kNm})$ required to pull trunk to a specified angle from vertical start position one and two growing seasons after planting for three root pruning treatments. Shaved and sliced were significantly greater than not pruned first growing season, and shaved was greater than sliced the second growing season at $P<0.07\left(^{*}\right)$ and $P<0.05\left(^{* *}\right)$. 
Table 4. Effect of three root pruning methods prior to landscape planting on circling roots inside root ball of Highrise live oaks.

\begin{tabular}{|c|c|c|c|c|c|c|c|c|}
\hline \multirow[t]{2}{*}{$\begin{array}{l}\text { Root pruning } \\
\text { method }\end{array}$} & \multicolumn{2}{|c|}{$\begin{array}{l}\text { Number of circling } \\
\text { roots }^{\mathrm{z}}\end{array}$} & \multicolumn{2}{|c|}{$\begin{array}{l}\text { Cross sectional area } \\
\text { of circling roots }\end{array}$} & \multicolumn{2}{|c|}{$\begin{array}{l}\text { Ratio of number of circling } \\
\text { roots }^{\mathrm{z}} \text { to non-circling roots }\end{array}$} & \multicolumn{2}{|c|}{$\begin{array}{l}\text { Ratio of CSA of circling } \\
\text { roots }^{z} \text { to non-circling roots }\end{array}$} \\
\hline & GS $1^{y}$ & GS 2 & GS 1 & GS 2 & GS 1 & GS 2 & GS 1 & GS 2 \\
\hline Not pruned & $8.9 \mathrm{a}^{\mathrm{x}}$ & $11.4 \mathrm{a}$ & $182 \mathrm{a}$ & $413 \mathrm{a}$ & $0.73 \mathrm{a}$ & $0.39 \mathrm{a}$ & $0.87 \mathrm{a}$ & $0.27 \mathrm{a}$ \\
\hline Sliced & $7.3 \mathrm{a}$ & $5.4 \mathrm{~b}$ & $157 \mathrm{a}$ & $271 \mathrm{~b}$ & $0.37 \mathrm{ab}$ & $0.23 \mathrm{~b}$ & $0.28 \mathrm{~b}$ & $0.15 \mathrm{~b}$ \\
\hline Shaved & $10.0 \mathrm{a}$ & $5.9 \mathrm{~b}$ & $139 \mathrm{a}$ & $205 \mathrm{~b}$ & $0.21 \mathrm{~b}$ & $0.17 \mathrm{~b}$ & $0.17 \mathrm{~b}$ & $0.09 \mathrm{~b}$ \\
\hline
\end{tabular}

${ }^{\mathrm{z}}$ Number of roots circling in an arc more than 90 degrees at any position inside original $10 \mathrm{~L}$ or $57 \mathrm{~L}$ container root ball.

y One growing season (GS 1) or two growing seasons (GS 2) after planting.

${ }^{x}$ Means in a column with a different letter are statistically different at $P<0.05$ using Duncan's multiple range test; based on eight trees per root pruning treatment averaged across nursery planting depths.

Table 5. Correlation between various root attributes and bending moment required to pull trunks ${ }^{2}$ to 20 degrees from vertical, and maximum bending moment required to pull trees out of ground.

\begin{tabular}{|c|c|c|c|c|}
\hline \multirow[t]{2}{*}{ Root attribute } & \multicolumn{2}{|c|}{$\begin{array}{l}\text { Moment while pulling trees to } \\
20 \text { degrees }\end{array}$} & \multicolumn{2}{|c|}{$\begin{array}{l}\text { Maximum moment while pulling } \\
\text { trees out of ground }\end{array}$} \\
\hline & $\begin{array}{l}\text { Pearson correlation } \\
\text { coefficient }\end{array}$ & $P$ value & $\begin{array}{l}\text { Pearson correlation } \\
\text { coefficient }\end{array}$ & $P$ value \\
\hline Cross sectional area (CSA) straight roots & 0.80 & $<0.0001$ & 0.33 & $<0.02$ \\
\hline CSA W+NW+SW (leeward) & 0.63 & $<0.0001$ & 0.76 & $<0.0001$ \\
\hline Total CSA & 0.55 & $<0.0001$ & 0.58 & $<0.0001$ \\
\hline CSA west (leeward) & 0.49 & 0.0007 & 0.52 & 0.0003 \\
\hline CSA E+NE+SE (windward) & 0.47 & 0.0011 & 0.35 & 0.0162 \\
\hline Total CSA top half of root ball & 0.39 & 0.0070 & 0.47 & 0.0010 \\
\hline CSA top half of root ball W (leeward) & 0.38 & 0.0093 & 0.33 & 0.0266 \\
\hline CSA top half of root ball W+NW+SW (leeward) & 0.37 & 0.0108 & 0.48 & 0.0009 \\
\hline CSA top half of root ball E+NE+SE (windward) & 0.30 & 0.0449 & 0.31 & 0.0368 \\
\hline CSA E (windward) & 0.24 & 0.1128 & 0.03 & 0.8326 \\
\hline CSA top half of root ball E (windward) & 0.22 & 0.1426 & 0.07 & 0.6531 \\
\hline
\end{tabular}

${ }^{\mathrm{z}}$ Data collected from all 48 trees, including 24 pulled at end of first growing season and 24 pulled end of second growing season after planting.

with total root CSA and root CSA in the windward direction growing into landscape soil (Gilman and Masters 2010). Stability in that study was also attributed to abundant large-diameter roots that grew straight from the trunk in a radial position without first curving or descending in the shape of the container.

Presence of straight horizontal roots, on forest trees up to 21-years-old, planted from propagation-sized containers, has also been associated with better stability following planting (Ortega et al. 2006) than trees with root deflections. Slicing (Ortega et al. 2006; Gilman et al. 2008) or shaving (Gilman et al. 2010b) root balls when planting in soil or when shifting from one container size to another, or growing trees in certain propagation containers (Gilman et al. 2010c), can increase number of straight roots in the root ball. However, there is some evidence that non-root pruned trees eventually may become as stable as those not root pruned at planting (Coutts et al. 1999). Data from the current study shows that roots can be encouraged to continue growing straight away from the trunk by shaving or deep slicing when planted into the landscape. This improved anchorage and reduced occurrence of circling roots that could develop into stem girdling roots.

There was evidence that shallow roots made a substantial contribution to anchorage since four attributes of roots growing from the top half of the root ball were significantly correlated with bending moment (Table 5). In contrast, attributes of roots growing from the bottom half of the root ball were never correlated with bending moment. Gilman and Masters (2010) also found that root $\mathrm{CSA}$ in the top $13 \mathrm{~cm}$ of soil profile was extremely important to lateral stability of live oak trees transplanted from a field nursery or planted from containers. Stability of trees in a forest setting with shallow soil was associated with characteristics of the shallow roots (Coutts 1986; Stokes 1999); deeper roots contribute substantially to stability on deeper soil (Mickovski and Ennos 2003).

\section{CONCLUSIONS}

Planting depth in the nursery container did not impact Highrise live oak trunk caliper and height either in the nursery for two years or for the first two growing seasons after planting into the landscape. However, results may have been different if this study was conducted under more stressful cultural conditions, such as in a soil type that drained poorly or under very dry conditions. Root pruning when planting into the landscape also had no measurable impact of top growth. Straight roots appeared to be among the most important attributes of well-anchored trees planted from these containers. Root pruning $57 \mathrm{~L}$ containers by either deep radial slicing or shaving off the periphery of the root ball (in both cases combined with removing all roots on the top edge of the root ball) at planting provided a simple means for creating straight roots. Both root pruning methods (deep radial slicing and shaving) reduced the number of circling roots while improving tree anchorage for the duration of this two-year study. Further study would be required to evaluate whether these relationships would hold true for longer periods of time, or in different soil types. 


\section{LITERATURE CITED}

Arnold, M.A. 1996. Mechanical correction and chemical avoidance of circling roots differentially affect post-transplant root regeneration and field establishment of container-grown Shumard oak. Journal of American Society Horticultural Science 121:258-263.

Arnold, M.A., and E. Young. 1991. $\mathrm{CuCo}_{3}$-painted containers and root pruning affect apple and green ash root growth and cytokinin levels. HortScience 26:242-244.

Blanusa, T., E. Papadogiannakis, R. Tanner, and R.W.F. Cameron. 2007. Root pruning as a means to encourage root growth in two ornamental shrubs, Buddleja davidii 'Summer Beauty' and Cistus 'Snow Fire'. Journal of Horticulture Science Biotechnology 82:521-528.

Brown, C., and K. Tilt. 1992. Effects of planting depth on three ornamental trees. Proceedings of the Southern Nurserymen Association Annual Conference 37:2-4.

Bryan, D.K., M.A. Arnold, A. Volder, W.T. Watson, L. Lombardini, L.J. Sloan, L.A. Valdez-Aguilar, and A.D. Cartmill. 2010. Planting depth during container production and landscape establishment affects growth of Ulmus parvifolia. HortScience 45:54-60.

Coutts, M.P. 1986. Components of tree stability in Sitka spruce on peaty, gley soil. Forestry 59:173-197.

Coutts, M.P., C.C.N. Nielson, and B.C. Nicoll. 1999. The development of symmetry, rigidity, and anchorage in the structural root system of conifers. Plant and Soil 217:1-15.

Gilman, E.F., and C. Harchick. 2008. Planting depth in containers affects root form and tree quality. Journal of Environmental Horticulture 26:129-134.

Gilman, E.F., C. Harchick, and C. Wiese. 2008. Pruning roots affects tree quality in container-grown oaks. Journal of Environmental Horticulture 27:7-11.

Gilman, E.F., C. Harchick, and M. Paz. 2010a. Planting depth affects root form of three shade tree cultivars in containers. Arboriculture \& Urban Forestry 36:132-139.

Gilman, E.F., M. Paz, and C. Harchick. 2010b. Root ball shaving improves root systems on seven species in containers. Journal of Environmental Horticulture 28:13-18

Gilman, E.F., M. Paz, and C. Harchick. 2010c. Effect of container type on root form and growth of red maple. Journal of Environmental Horticulture 28:1-7.

Gilman, E.F., and F.J. Masters. 2010. Effect of tree size, root pruning, and production method on root growth and lateral ability of Quercus virginiana. Arboriculture \& Urban Forestry 36:281-291.

Gilman, E.F., and J. Grabosky. 2011. Quercus virginiana root attributes and lateral stability after planting at different depths. Urban Forestry \& Urban Greening 10:3-9.

Gilman, E.F., T.H. Yeager, and D. Weigle. 1996. Fertilizer, irrigation, and root ball slicing affects Burford holly growth after planting. Journal of Environmental Horticulture 14:105-110.

Halter, M.R., C.P. Chanway, and G.J. Harper. 1993. Growth reduction and root deformation of containerized lodgepole pine saplings 11 years after planting. Forest Ecological Management 56:131-146.

James, K.R, and B. Kane. 2008. Precision digital instruments to measure dynamic wind loads on trees during storms. Agricultural and Forest Meteorology 148:1055-1061.

Krasowski, M.J., and J.N. Owens. 2000. Morphological and physical attributes of root systems and seedlings growth in three different Picea glauca reforestation stock. Canadian Journal of Forestry Research 30:1669-1681.
Lindstrom, A., and G. Rune. 1999. Root deformation in plantations on container-grown Scots pine trees: effects on root growth, tree stability and stem straightness. Plant and Soil 217:29-37.

Lyons, C.G., Jr., R.E. Byers, and K.S. Yoder. 1983. Influence of planting depth on growth and anchorage of young 'Delicious' apple trees. HortScience 18:923-924.

Mickovski, S.B., and A.R. Ennos. 2003. Anchorage and asymmetry in the root system of Pinus peuce. Silva Fennica 37:162-173.

Nichols, T.J,. and A.A. Alm. 1983. Root development of containerreared, nursery-growth, and naturally regenerated pine seedlings. Canadian Journal of Forest Research 13:239-245.

Ortega, U., J. Majada, A. Mena-Petite, J. Sanchez-Zabala, N. RodriguezItturrizar, K. Txarterina, J. Azpitarte, and M. Duñabeitia. 2006. Field performance of Pinus radiata D. Don produced in nursery with different types of containers. New Forests 31:97-112.

Persson, P. 1978. Some possible methods of influencing the root development of containerized tree seedlings. Proceedings of the Symposium on Root Form of Planted Trees, Victoria, B.C., Canada. May 16-19. pp. 295-300.

Sparks, D. 2005. Tree setting depth affects wind resistance in pecan. Journal American of Pomology Society 59:134-140.

Stokes, A. 1999. Strain distribution during anchorage failure of Pinus pinaster Ait. at different ages and tree growth response to wind-induced root movement. Plant and Soil 217:17-27.

Welcherding, P.J., C.P. Giblin, J.H. Gillman, D, L. Hanson, and G. Johnson. 2007. Mechanical root-disruption practices and their effect on circling roots of pot-bound Tilia cordata Mill. and Salix alba L. 'Niobe'. Arboriculture \& Urban Forestry 33:43-47.

Edward F. Gilman (corresponding author)

Environmental Horticulture Department

University of Florida

Gainesville, FL 32611

egilman@ufl.edu

Christine Wiese

Environmental Horticulture Department

University of Florida

Gainesville, FL 32611

hibiscus@ufl.edu 
Résumé. Des Quercus virginiana Mill. Highrise ${ }^{\ominus}$ ont été mis en terre dans des contenants de production en plastique de $10 \mathrm{~L}$ et $57 \mathrm{~L}$ et à deux profondeurs différentes - pour un total de quatre combinaisons de profondeur et de dimension de pots - et leur racines ont par la suite été taillées selon une parmi trois manières différentes lorsque les plants ont été mis en pleine terre. La profondeur de plantation en pépinière n'avait pas d'impact sur la croissance en pépinière ou encore sur le moment de flexion requis pour incliner le tronc durant les deux premières années de la plantation en pleine terre. La taille des racines selon n'importe quelle méthode testée n'avait pas d'effet sur la croissance durant les deux premières années suivant la plantation en pleine terre. Le nombre de racines cerclantes à l'intérieur de la motte de terre était plus faible avec un rasage ou une coupe profonde de la motte deux saisons de croissance après la plantation en pleine terre. Les mottes qui avaient été coupées ou rasées produisaient plus de racines dans le sol une saison de croissance après leur plantation en pleine terre par rapport aux plants dont les racines n'avaient pas été coupées, ce qui expliquait probablement le moment de flexion plus important requis après la plantation en pleine terre pour tirer les arbres hors du sol. La superficie transversale totale en racines une saison de croissance après la plantation en pleine terre était plus grande chez les arbres rasés que chez ceux dont les racines n'avaient pas été coupées lors de la plantation. Le moment de flexion requis pour incliner le tronc de 20 degrés était corrélé de la manière la plus forte avec la superficie transversale des racines qui poussaient au travers de la périphérie de la motte lorsque le plant était en pot et lorsqu'il était en pleine terre.

Zusammenfassung. Quercus virginiana Mill. Highrise ${ }^{\circledR}$ wurden erst in 10 1, dann in 571 Plastikcontainern mit zwei Pflanztiefen in insgesamt vier Tiefenkombinationen gepflanzt und anschließend beider Pflanzung in die Freifläche wurden die Wurzeln auf drei verschiedene Arten zurückgeschnitten. Die Pflanztiefe in der Baumschule hatte keinen Einfluss auf das Wachstum in der Baumschule oder auf das erforderliche Biegemoment zum Kippen des Stammes in den ersten zwei Jahren nach der Verpflanzung in die Landschaft. Der Wurzelrückschnitt hatte bei keiner getesteten Methode einen Einfluss auf das Wachstum in den ersten zwei Jahren nach der Verpflanzung. Die Anzahl der Würgewurzeln innerhalb des Wurzelballens wurde durch eine Rasur oder tiefes Schlitzen des Wurzelballens zwei Wachstumsperioden nach der Verpflanzung reduziert. In der Wachstumsperiode nach der Verpflanzung produzierten geschlitzte oder rasierte Wurzelballen mehr Wurzeln im Freiland als die unbeschnittenen, was wahrscheinlich den größeren erforderlichen Biegemoment zum Herausziehen der Ballen erklärt. Die totale Wurzelquerschnittsfläche in der ersten Wachstumsperiode nach der Pflanzung in Freie war größer bei rasierten Bäumen als bei unbeschnittenen Bäumen. Das Biegemoment bei 20 Grad Stammneigung war am besten korreliert mit der Wurzelquerschnittsfläche der Wurzeln, die grade aus der Peripherie des Wurzelballens in den Landschaftsboden wuchsen.

Resumen. Quercus virginiana Mill. Highrise ${ }^{\circledR}$ fueron plantados en contenedores de plástico de vivero de $10 \mathrm{~L}$, y luego de $57 \mathrm{~L}$, a dos profundidades para un total de cuatro combinaciones de profundidad y luego poda de raíz en una de tres maneras diferentes cuando se plantaron en el paisaje. La profundidad de siembra no tuvo ningún impacto sobre el crecimiento en el vivero o momento de flexión requerido para inclinar los troncos en los dos primeros años tras la plantación en el paisaje. La poda de raíz cuando se plantaron en el paisaje por cualquiera de los métodos probados no tuvo efecto sobre el crecimiento en los dos primeros años. Se redujo el número de raíces enrolladoras dentro de la bola de la raíz por el rebanado o por corta de raíces profundas, dos temporadas de crecimiento después de la plantación. Los cepellones que fueron rebanados o cortados generaron más raíces en el suelo del paisaje una temporada de cultivo después de la plantación, que aquellos que no fueron podados en la raíz, lo que probablemente explica la mayor flexión necesaria para derribar los árboles. El área transversal total de las raíces, una temporada de crecimiento después de la siembra en el paisaje, fue mayor en árboles rebanados que en los no podados en la raíz al momento de la plantación. El momento flector a 20 grados de inclinación del tronco se correlacionó mejor con el área transversal de las raíces creciendo directamente a través de la periferia de la bola de la raíz y en el suelo del paisaje. 